\title{
Development of Kulfi Incorporated with Amaranthus (Rajgara)
}

\author{
A.C. Patel", A.J. Pandya, G. Gopikrishna, R.A. Patel, A.M. Shendurse and S.K. Roy
}

Dairy Technology Department, G N Patel College of Dairy Technology, Sardarkrushinagar Dantiwada Agricultural University, Sardarkrushinagar, Banaskantha-385506, Gujarat, India

*Corresponding author

\section{A B S T R A C T}

\section{Keywords}

Kulfi, Amaranthus, Physico-chemical properties,

Viscosity,

Melting rate

\section{Article Info}

\section{Accepted:}

05 April 2020

Available Online:

10 May 2020
Since no attempt has been made to produce Kulfi using Amaranthus, the present investigation was carried out with the objective of developing Kulfi by using Amaranthus. Kulfi Mix was standardized to $10 \%$ fat, $10 \%$ SNF, $15 \%$ sugar and $0.15 \%$ stabilizer. Part of SMP was replaced by adding the amaranths flour. Amaranths: SMP in Kulfi mix was added in ratios of 25:75 (T1), 50:50 (T2), 75:25 (T3), 100:0.0 (T4) and 0.0:100 (T5). Formulated Kulfi mix, was pasteurized, followed by cooling at $4{ }^{\circ} \mathrm{C}$. Artificial flavours i.e. Mawa flavour was added @ $0.3 \%$ by wt of the mix. Then the Kulfi mix was filled in to the Kulfi mould covered with the lid and transferred to candy making machine, set at $-20^{\circ} \mathrm{C}$ for freezing. After complete freezing, Kulfiwas transferred to deep freezer maintained at $18 \pm 2{ }^{\circ} \mathrm{C}$ (for overnight) for hardening. The fat and other carbohydrate content of Kulfi significantly $(\mathrm{P}<0.05)$ increased with the increased in the proportion of Amaranthus. The protein, lactose and ash content of Kulfi significantly $(\mathrm{P}<0.05)$ decreased with increased in the proportion of Amaranthus. The TS, acidity and $\mathrm{pH}$ of Kulfi remained statistically unchanged with increased in the proportion of Amaranthus. The viscosity and Melting rate of Kulfi significantly ( $\mathrm{P}<0.05$ ) increased and decreased respectively, with increased in the proportion of Amaranthus. The highest mean score of flavour, body and texture, colour and appearance and overall acceptability were obtained in experimental Kulfi i.e. T1 (Amaranthus: SMP @ 25:75). The cost of production of Amaranthus based Kulfi per single unit/ piece of $60 \mathrm{ml}$ was estimated to be Rs 7.087, which appeared to be reasonably competitive. The energy value that can be gained through consumption of $100 \mathrm{~g}$ of developed Kulfi is 195.891 kcal.

\section{Introduction}

Kulfi is an indigenous frozen milk product which is particularly popular in the northern part of India. It is often called as Indian ice cream. It comprises higher total solids per unit volume as compared with the ice cream. It is defined as frozen mixture of milk, cream, condensed milk and dried milk with the addition of non-milk products for sweetening stabilizing and flavouring (Yerriswamy et al., 1983). It is widely manufactured and marketed by the unorganized sector, especially during summer. The method of production varies from producer to producer. For preparation of Kulfi, cow or buffalo or 
mixed milk is concentrated and added with sugar, nuts and spices followed by freezing eutectic mixture consist of ice and salt as 4:1. It is offered in many flavours, including cardamom, mango, avocado, pistachio, orange, malai, apple, peanut, and saffron.

In India about $0.7 \%$ of the total milk is converted in to Kulfi, ice cream and other frozen dessert. Per capita consumption of these frozen desserts in India is about 300 ml/annum which are much lower as compared with the world average of 2.3 litre/annum, with USA at its remarkably 22 litre/annum (Naik and Londhe, 2011). Despite low consumption of frozen desserts the Indian frozen dessert industry is valued at about 20 billion with a yearly growth rate of $15 \%$. In the industry $40 \%$ is handled by organized sector. The key player of frozen dessert in Indian market is Amul with a market share of about 36-38 \% followed by Kwality walls and Vadilal each having market share of 12-14\% (Anonymous 2015).

As per FSSR (2011), the Kulfishall contain minimum $10 \%$ fat, $3.5 \%$ protein and $36 \%$ total solids.

\section{Materials and Methods}

\section{For Kulfi}

Methodologies related to the technological, physic-chemical and sensorial aspects are delineated hereunder.

\section{Ingredients/ Materials}

Raw materials such as milk, Amaranthus flour, sugar, stabilizer \& emulsifier, spices \& condiments, and Artificial/Natural flavours and colourants were used in the experiment. Milk / Skim milk / Cream

were obtained from the fresh, raw mixed (cow and buffalo) milk received at Mini Dairy
Plant of GN Patel College of Dairy Technology. Good quality Amaranthus free from stones, dust, insects and other impurities was procured from local market for preparation of Kulfi. Good quality commercial grade cane sugar, procured from the local market was used for preparing sugar syrup. Stabilizer i.e. sodium alginate was used for manufacturing of Kulfi, was obtained from the local market of Palanpur. Artificial/Natural flavours i.e. Mawa flavour used for manufacturing of Kulfi, was obtained from the local market of Palanpur.

All the chemicals, used for this study were of AR grade. The equipment used in the investigation was as follows: cream separator, Kulfi mould, candy making machines, hardening tunnels and storage unit.

\section{Preparation of Kulfi}

\section{Amaranthus based Kulfi}

Kulfi mix was prepared using milk, cream, skim milk powder, Amaranthus flour, sugar, stabilizer i.e. sodium alginate @ $0.15 \%$ and artificial/natural flavours i.e Mawa flavour. It was standardized to $10 \%$ fat, $10 \%$ SNF and $15 \%$ sugar. Part of SNF was adjusted by adding the Amaranthus flour. Amaranthus: SMP in Kulfi mix was added in a 25:75 (T1), 50:50 (T2), 75:25 (T3), 100:0.0 (T4) and 100:0.0 (T5) ratios. Formulated Kulfi mix was pasteurized at $80{ }^{\circ} \mathrm{C}$ for $25 \mathrm{sec}$. followed by cooling at $4{ }^{\circ} \mathrm{C}$. Artificial/Natural flavours i.e Mawa flavor@0.3\% was added to the mix. Then the Kulfi mix was filled in to the Kulfi mould covered with the lid. Moulds were transferred to candy making machine, set at $20{ }^{\circ} \mathrm{C}$ for freezing. After complete freezing, Kulfi was transferred to deep freezer maintained at $-18 \pm 2{ }^{\circ} \mathrm{C}$ (for overnight) for hardening. The Kulfi was kept in deep freezer until further used. Four different experimental Kulfi i.e. T1 (25\% replacement of SMP), T2 (50 \% replacement of SMP), T3 (75\% 
replacement of SMP) and T4 (100\% replacement of SMP), were prepared. Different proportions of Amaranthus flour in Kulfi as indicated in Table 3.2.

\section{Control Kulfi}

The control Kulfi sample (i.e. T5) was prepared without addition of Amaranthus flour in Kulfi mix, which was standardized to $10 \%$ fat and $10 \% \mathrm{MSNF}$ and $15 \%$ sugar. SNF was adjusted with the skim milk powder only.

\section{Physico-chemical analysis}

The total solid of the product was determined by gravimetric method (AOAC, 1995).Fat content of Kulfi was determined by RoseGottliebe Method as described by AOAC 905.02 (2000) for fat in milk with slight modification method. The protein content of the product was determined by measuring the total nitrogen content as described by AOAC official method (1995) and multiplying the total nitrogen by 6.38. Ash content of the product was determined gravimetrically by incinerating the sample in muffle furnace at $550{ }^{\circ} \mathrm{C}$ as described in IS: SP: 18 , Part XI, 1981.The $\mathrm{pH}$ of Kulfi was measured using digital $\mathrm{pH}$ meter. The method described by Franklin and Sharpe (1963) for cheese was used. About $20 \mathrm{ml}$ of sample was taken for measuring the $\mathrm{pH}$ directly.TitratableAcidity of the product was determined by titramic method as described in IS: 1166-1973 specification for condensed milk. Lactose content of the product was determined as per BIS Procedure (IS: SP: 18, Part XI, 1981) for condensed milk. Other carbohydrate was derived by difference of sum total of the major constituents like moisture, protein, fat, lactose and ash from total solids. Viscosity of Kulfi mix was measured by using the Brookfield viscometer. Melting rate was determined by emptying the Kulfi samples from the moulds on an iron mesh (9 squares per linear inch) placed over a glass funnel having $10 \mathrm{~cm}$ outside diameter as suggested by Ashokraju et al., (1989). The whole assembly was kept over a preweighed glass measuring cylinder (capacity $100 \mathrm{ml}$ ) and placed in an oven maintained at $30^{\circ} \mathrm{C}$ without air circulation. The weight of the cylinder was taken after 30 minutes and difference in weight is expressed as melting rate in grams per 30 minutes.

\section{Sensory evaluation}

Experimental and control samples of Kulfi were organoleptically evaluated using 9 point hedonic scale by a panel of trained judges. Optimized product was also evaluated with control Kulfi.

\section{Results and Discussion}

The effect of different levels of Amaranthus on sensorial and physico-chemical properties of developed product was evaluated. The results obtained during investigation on different aspects of Kulfi are presented and discussed hereunder.

\section{Effect of rate of addition of Amaranthus on physico-chemical properties of Kulfi}

To study the influence of rate of addition of Amaranthus on physic-chemical attributes of experimental samples of Kulfi were analyzed for their total solids, fat, protein, ash, lactose, other carbohydrate, acidity, $\mathrm{pH}$, viscosity and melting rate (Table 1).

Means with at least one letter common are not statistically significant using Fisher's Least Significant difference, Figures placed after \pm indicates Standard Error of Mean, other carbohydrate was obtained by difference, all the values are in per cent except for $\mathrm{pH}$, Viscosity and Melting rate. Acidity expressed 
as lactic acid, Viscosity expressed in $\mathrm{cP}$ measured at $25^{\circ} \mathrm{C}$, Melting rate expressed in $\mathrm{mg} / 30 \mathrm{~min}$.

\section{Total solid}

The data obtained for total solid content of Kulfi are presented in Table 1. Addition of Amaranthus: SMP in different ratio had no any significant effect $(\mathrm{P}<0.05)$ on total solid. The total solid content of Kulfi added with five different proportions of Amaranthus: SMP i.e. T1 (25:75), T2 (50:50), T3 (75:25), T4 (100:00) and T5 (00:100) were found $36.28,36.20,36.16,36.09$ and 36.31 per cent respectively. The total solids content of all the treatments were statistically at par with each other. It can be seen from the table that with increase in the rate of addition of Amaranthus, total solid content of Kulfi decreased concurrently. This may be attributed to the reason that the higher $\mathrm{TS}$ content of SMP i.e. 96.5\%, which was replaced by the Amaranthus flour having 90.5 $\%$ of TS.

The results obtained in present study for the total solid of Kulfi was in the range similar with the Nigam (2015) who reported that the total solids content of the Chhana based Kulfi samples varied from 30.3 to $38.4 \%$. Rao (1978) reported that the market sample of Kulfi had a TS content ranging from 30.10 to $49.30 \%$. Salooja (1979); Salooja and Balachandran (1982) revealed that the experimental Kulfi had a $39.0 \%$ of TS. Yerriswamy et al., (1984) reported that Kulfi mixes containing 37 to $40 \%$ total solids and heat treated at $121{ }^{\circ} \mathrm{C}$ for 15 minutes produced very good quality Kulfi in terms of organoleptic scores. Yerriswamy et al., (1983) reported that the market and experimental Kulfi had \% TS content in the range of 36.0 to 41.4 and 38.2 to 40.2 respectively. Ghosh (1991) documented the TS content of market sample Kulfi was 33.95 to $49.13 \%$. Ravindran (2003) found that the experimental Kulfi had $39.84 \%$ TS.

\section{Fat}

The data obtained for fat content of Kulfi are presented in Table 1. The fat content of experimental Kulfi was found in range from 10.03 to 10.23 per cent. The fat content of experimental Kulfi added with four different proportions of Amaranthus: SMP and control Kulfi (i.e. T1, T2, T3, T4 and T5) were found $10.06,10.13,10.17,10.23$ and 10.03 per cent, respectively. The fat content of the experimental Kulfi sample showed significant $(\mathrm{P}<0.01)$ increased as increased rate of addition of Amaranthus. The fat content was higher in T4 $(10.23 \%)$ as compared to other treatments while the values of fat content of Kulfi in case of T1;T2, T2;T3 and T3;T4 were statistically at par with each other.

The fat content of experimental Kulfi was similar with those reported by Thomas et al., (2019) who observed that the level of oat flour increased from 0 to 6 per cent the fat content of lactose hydrolyzed Kulfi also increased significantly from 10.12 to 10.53 per cent.

The supplementation of oat flour at 2, 4 and 6 per cent levels contributed towards the increased fat percentages of 10.26, 10.39 and 10.53 compared to that of 10.12 per cent in control.

Patel et al., (2015a) reported that the incorporation of ragiflour in ice cream mix also tended to increase the fat content of experimental Kulfi. Siva et al., (2019) described that the \% fat of Kulfi prepared with $0 \%, 5 \%, 10 \%, 15 \%$ and $20 \%$ flaxseed powder were 11.89, 15.54, 19.17, 22.73 and 24.64 respectively. The fat content of Kulfi increased significantly with increased in rate of addition of Amaranthus. 


\section{Protein}

The average protein content of Kulfi along with their statistical analysis is depicted in Table 1. Protein content of four types of experimental Kulfi and control Kulfi was found in range from 3.60 to 4.02 per cent. The protein content was higher in control $(4.02 \%)$ and lower in T4 prepared with Amaranthus: SMP in the proportion of 100:00. Addition of Amaranthus at different rate had significant effect $(\mathrm{P}<0.01)$ on protein content of Kulfi. The values for protein content of all the experimental and control Kulfi were statistically differ with each other. It is revealed from the protein content of Kulfi that increase in the rate of addition of Amaranthus, the protein content of Kulfi decreased simultaneously. The reason behind the lowering in protein content is due to the lesser amount of protein in Amaranthus i.e. $13.33 \%$ as per USDA (2018) compare to the skim milk powder i.e. $36 \%$.

The same trend was observed by Salama et al., (2017) who reported that with increasing replacement levels of fresh skimmed milk and skimmed milk powder with oat or/and barley, the contents of protein of the resultant ice milks decreased from 4.565 in control to 2.309 in experimental ice milk. The protein content of Chhanabased Kulfi was $6.95 \%$ (Nigam, 2015). Siva et al., (2019) reported that the protein content of Kulfi prepared with $0 \%, 5 \%, 10 \%, 15 \%$ and $20 \%$ flaxseed powder was found in the range of 7.46 to 8.36 per cent.

\section{Lactose}

The average values for lactose of Kulfi, manufactured in this experiment are collated in Table 1. It can be seen from the table that the experimental Kulfi i.e. T4 was significantly $(\mathrm{P}<0.01)$ differed from all other experimental and control sample.The average mean value for lactose content of Kulfi varies from 5.13 to $5.43 \%$. It can be seen from the table that lactose content of Kulfi was decreased with increased in the rate of addition of Amaranthus. The control sample of Kulfi carries the maximum value for lactose content i.e. $5.43 \%$ and minimum value associates with $\mathrm{T} 4$ (i.e. 5.13) which contains highest level of Amaranthus. This is attributed to the reason that the Amaranthus is devoid of lactose according to USDA (2018), unlike the SMP which contain $55 \%$ led to decrease in lactose content of experimental Kulfi sample with increased in to the level of Amaranthus. Our findings can be compared with the findings of Nigam (2015) who revealed that the Chhana based Kulfi contained $2.28 \%$ lactose. The experimental Kulfi were ranked in the order of $\mathrm{T} 5>\mathrm{T} 1>\mathrm{T} 2>\mathrm{T} 3>\mathrm{T} 4$ in their lactose content.

\section{Other carbohydrate}

The tabulated values for other carbohydrate content of Kulfi made using different levels of Amaranthus: SMP, increased with increased in the proportion of Amaranthus. The average values of other carbohydrate for experimental and control samples were in the range of $16.03 \%$ (T5) to $16.40 \%$ (T4).The statistical analysis in Table 1 shows that there was significant $(\mathrm{P}<0.05)$ effect of level of Amaranthus: SMP [viz. 25:75 (T1), 50:50 (T2), 75:25 (T3), 100:00 (T4) and 00:100 (T5)] on the other carbohydrate content of the experimental Kulfi. The maximum value for other carbohydrate content associated with T4 sample prepared from the level of Amaranthus: SMP in the ratio of 100:00 whereas lower value associated with the control Sample (T5), prepared using only SMP. Since, According to USDA (2018), the carbohydrate content of Amaranthus flour is $66.67 \%$ compare to $51 \%$ of skim milk powder. Hence increase in concentration of Amaranthus in Kulfi led to increase in other 
carbohydrate content of experimental sample. The experimental and control Kulfi were ranked in the order of $\mathrm{T} 4>\mathrm{T} 3>\mathrm{T} 2>\mathrm{T} 1>\mathrm{T} 5$ in their other carbohydrate content.

This results is in agreement with the findings of Salama et al., (2017) who found that the replacement of fresh skimmed milk and skimmed milk powder with oat or/and barley, led to significantly increased in other carbohydrate content of ice milks from 19.874 $\%$ for control to $22.472 \%$ for experimental sample. This is due to oats and barley's milk and oats and barley's powder used in treated ice milk mixes had the highest amount of carbohydrates compared to fresh skimmed milk and skimmed milk powder. The other carbohydrate content of Chhanabased Kulfi was $18.7 \%$ reported by Nigam (2015).

\section{Ash}

The tabulated values for the ash content of Kulfi made using different levels of Amaranthus: SMP, decreased with increased in the proportion of Amaranthus. The average values of ash for experimental samples were in the range of $0.74 \%$ (T1) to $0.80 \%$ (T5). The statistical analysis in Table 1shows that there was significant $(\mathrm{P}<0.05)$ effect of level of Amaranthus: SMP (viz. 25:75, 50:50, $75: 25,100: 00$ and 00:100) on the ash content of the experimental Kulfi. It is evident from the table that ash content of Kulfi was decreased with increased in the rate of addition of Amaranthus. Since, According to USDA (2018), the ash content of Amaranthus flour is $2.88 \%$ compare to $7 \%$ of skim milk powder. Hence increased in concentration of Amaranthus and decreased in SMP content of Kulfi led to decrease in ash content of experimental sample.

This result is in covenant with the findings of Salama et al., (2017) who found that the replacement of fresh skimmed milk and skimmed milk powder with oat or/and barley, led to significantly decrease in ash content of ice milks from $0.971 \%$ for control to $0.629 \%$ for experimental sample. Nigam (2015) reported that the ash content of Chhana based Kulfi is $0.73 \%$. Siva et al., (2019) stated that the ash content of Kulfi prepared with $0 \%, 5$ $\%, 10 \%, 15 \%$ and $20 \%$ flaxseed powder was found to be $0.97,1.10,1.21,1.30$ and 1.41 per cent respectively. Ash content of experimental Kulfi decreased significantly with increased in rate of addition of Amaranthus.

\section{Titratable acidity}

Table 1shows the acidity value assigned to each experimental and control Kulfi. All the experimental sample were statistically $(\mathrm{P}<$ $0.05)$ at par with each other. The mean values of acidity for all the experimental and control Kulfi were $0.16 \%$.

The results is in consonance with the outcome obtained by Yerriswamy et al., (1983) who reported the acidity of experimental and market Kulfi sample ranged from 0.16 to 0.18 and 0.18 to $0.22 \%$ respectively. Yerriswamy et al., (1984) also reported that Kulfi mix subjected to sterilize at $121^{\circ} \mathrm{C}$ for 10,15 and 20 min. period, the acidity of Kulfi mix with 37 to $40 \% \mathrm{TS}$, increased from 0.22 to 0.28 $\%$. Nigam (2015) reported the acidity of Chhana based Kulfi and conventional Kulfi were $0.27 \%$. Salooja (1979) reported that the average acidity values of Kulfi mix prepared with 17, 20, 23, 26 and 29 per cent MSNF were $0.187,0.217,0.236,0.286$ and 0.383 per cent lactic acid respectively. Siva et al., (2019) stated that the titratable acidity of Kulfi with $0 \%, 5 \%, 10 \%, 15 \%$ and $20 \%$ flaxseed powder, was found in the range of 0.22 to $0.31 \%$ lactic acid. Addition of Amaranthus was not statistically distinguished the acidity of resultant Kulfi. 
pH

The average values for $\mathrm{pH}$ of control and experimented samples are presented in Table 1 . The $\mathrm{pH}$ values varied in a narrow range of 6.79 (T2, T3, T5) to 6.81 (T1).The tabulated scores and relevant statistical analysis showed that there was not any statistical significant $(\mathrm{P}$ $<0.05$ ) difference found in the $\mathrm{pH}$ of experimental Kulfi. T1 sample had higher $\mathrm{pH}$ value i.e. 6.81 than all other sample. The $\mathrm{pH}$ values of the resultant experimental Kulfi was non-significant with the addition of Amaranthus. Addition of Amaranthus did not affect the $\mathrm{pH}$ value of Kulfi.

Nigam (2015) reported that the $\mathrm{pH}$ value of Chhana based Kulfi was 5.97. The $\mathrm{pH}$ value of market and experimental sample of Kulfi were in the range of 6.06 to 6.25 and 6.28 to 6.35 respectively (Yerriswamy et al., 1983). The $\mathrm{pH}$ of a Kulfi mix with total solids from $37 \%$ to $40 \%$ was subjected to sterilization, was from 5.96 to 6.06 (Yerriswamy et al., 1984). Salooja (1979) reported that the average $\mathrm{pH}$ values of Kulfi mix prepared with 17, 20, 23, 26 and 29 per cent MSNF were $6.62,6.52,6.50,6.41$ and 6.32 respectively. Addition of $0.15 \%$ sodium alginate in Kulfi mix containing $48.12 \%$ total solid was found to increase the $\mathrm{pH}$ value from 6.25 to 6.30 (Ashokrajuet al., 1989).

\section{Viscosity}

The data obtained for viscosity of Kulfi are presented in Table 1. Viscosity of four types of experimental Kulfi and control Kulfi were found in range from 27.18 to $30.26 \mathrm{cP}$. The viscosity of control sample (T5) was 27.18 cP. The viscosity of experimental Kulfi prepared with four different proportions of Amaranthus: SMP i.e. T1 (25:75), T2 (50:50), T3 (75:25) and T4 (100:00) were found 27.44, $28.52,29.26$ and $30.26 \mathrm{cP}$ respectively. It was evident from statistical analysis that the addition of Amaranthus at different rate had significant effect $(\mathrm{P}<0.01)$ on viscosity of Kulfi. The viscosity of T4 sample was higher than any other sample. All the treatment of Kulfi were statistically $(\mathrm{P}<0.01)$ significant with each other. Viscosity of Kulfi was tended to increase with increasing level of addition of Amaranthus.

The result was in accordance with those reported by Patel et al., (2015a) who determined that incorporation of ragiin various forms tended to increase the viscosity of mixes significantly since it is a good source of starch and fibers. A significant increase in viscosity with higher starch content was noted by Li et al., (1997); Prindivelle et al., (1999). Gelatinized ragistarch has water holding capacity of $10.9 \mathrm{ml} / \mathrm{g}$ has been reported for ragistarch (Mohan et al., 2005) and it can influence the rheological properties of ice cream mix (Guinard et al., 1994) so undoubtedly increased in quantity of gelatinized ragi, result in increase in viscosity (Muse and Hartel 2004; Rosalina et al., 2004). Patel et al., (2009) reported that addition of sago in gelatinized form increased the viscosity of ice cream mixes. Cody et al., (2007) indicated addition of rice flour increased viscosity of ice cream mix. Cottrell et al., (1980) also reported that polysaccharides such as starch increased the mix viscosity and restricted ice crystal growth during storage of ice cream. Schmidt et al., (1993) found that the use of carbohydratebased fat replacers in reduced fat ice creams resulted in mixes with higher viscosities. Siddhu et al., (2017) stated that Kulfi prepared using 3, 4 and $5 \%$ of each pineapple pomace, orange pomace and pomegranate pomace having viscosity for pineapple pomace Kulfi were 26.26, 27.24 and $26.89 \mathrm{cP}$ respectively, for orange pomace Kulfi were 28.78, 29.27 and $29.78 \mathrm{cP}$ respectively, and for pomegranate pomace Kulfi were 29.54, 27.66 and $28.25 \mathrm{cP}$ respectively. 


\section{Melting rate}

Meltdown behavior provides insights into key phenomena in frozen products such as protein stability, fat agglomeration and air cell size, which influence body, texture and other sensory characteristics. Furthermore, meltdown is an important part of any consumer's perception of product quality. Melting rate of Kulfi prepared using Amaranthus, varied from 30.04 to $38.69 \mathrm{~g} / 30$ min. (Table 1). It is revealed from the table that the level of Amaranthus increased, the melting rate decreased as Amaranthus contains higher amount of starch.

T4 had the highest melting resistance whereas T5 (i.e. Control) had the lowest melting resistance. The melting rate of all the experimental and control Kulfi sample were statistically $(\mathrm{P}<0.01)$ significant with each other. The results indicate that addition of Amaranthus significantly $(\mathrm{P}<0.01)$ increased the melting resistance of Kulfi. The higher melting resistance of experimental Kulfi could be due to the higher viscosity resulting from incorporation of Amaranthus at higher amounts. The viscosity of T4 mix was also found to be higher than all the other samples.

These results are also in agreement with Thomas et al., (2019) who revealed that the level of addition of oat flour increased from 0 to 6 per cent, the melting rate decreases significantly from 18.57 to $13.49 \mathrm{ml} / 15 \mathrm{~min}$, indicating that as the level of fiber increases greater quantities of water being bound by fiber, reducing the portion of free water resulting in significantly lower meting rate of Kulfi samples and as a result harder, compact body of Kulfi. These findings are in agreement with that of Giri (2007) who reported a significant reduction in melting rate of control and Kulfi with 1 per cent dietary fiber were $12.58 \mathrm{ml} / 15 \mathrm{~min}$ and 10.52 $\mathrm{ml} / 15$ min respectively. Singh et al., (2017b) reported that the increased in melting resistance values may be due to the presence of soluble dietary fiber or carbohydrate which forms a complex matrix which binds and holds the water resulting in slow melting.

\section{Effect of different rate of Amaranthus on sensory attributes of Kulfi}

Acceptability of product by consumers was mainly perceived by means of flavour, colour and appearance, body and texture, and overall acceptability. To select the preferred level of addition of Amaranthus, sensory evaluations were carried out by semi trained judges. The results obtained in this section represented the influence of addition of Amaranthus at various levels on the sensory attributes of Kulfi. The data of sensory scores are depicted in Table 2.The addition of Amaranthus had a significant effect $(\mathrm{P}<0.05)$ on flavour, body and texture, colour and appearance and overall acceptability scores of Kulfi.

\section{Flavour}

The flavour score of Amaranthus based Kulfi samples varied from 7.32 to 8.29. The minimum flavour score was obtained for the Kulfi formulation prepared from mix containing 100 parts of Amaranthus and maximum for the sample prepared from mix containing Amaranthus: SMP in the proportion of 25:75. The flavour score of Kulfi made using Amaranthus: SMP @ 25:75 was significantly $(\mathrm{P}<0.05)$ superior to those made using 50:50, 75:25, 100:00 and 00:100 proportions; Judges also noticed Amaranthus flavour in experimental Kulfi. It is revealed from the table that the flavour score for experimental Kulfi decreased with increased in the level of Amaranthus. All the experimental Kulfi had a pleasant, sweet, rich taste, however the subtle balance between sweetness and flavour was found to be superior in case of Kulfi prepare using Amaranthus: SMP in the proportion of 25:75. 
Our finding is in agreement with findings of Thomas et al., (2019) who observed that the flavour scores for oat Kulfi also shown decreasing trend as addition of oat flour increased. This may be due to the detectable powdery flavour contributed by the oat flour. Chatterjee and Patel (2016) reported similar trend in 3 per cent oat fiber added chocolate flavoured milk. They observed that fiber addition decreased overall flavour quality (control- 7.45, sample- 7.23). Giri (2007) also observed a reduction in flavour score in Kulfi from 8.0 to 5.9 when the Kulfi is supplemented with 1 per cent dietary fiber.

\section{Body and texture}

The body and texture score of Amaranthus based Kulfi samples varied from 7.36 to 8.21. The minimum body and texture score was obtained in the Kulfi prepared from mix containing Amaranthus: SMP in the ratio of 100:00, whereas the maximum score was recorded for the samples containing Amaranthus: SMP in the ratio of 25:75.The body and texture score of Kulfi made using Amaranthus: SMP in the proportion of 25:75 (T1) was significantly $(\mathrm{P}<0.05)$ greater than the respective score allotted to product made using 50:50 (T2), 75:25 (T3), 100:00 (T4) and 00:100 (T5) proportions. The experimental sample T1 and control sample is statistically at par with each other. Likewise, adverse impact on body and texture of Kulfi when adopting higher concentration of Amaranthus has been noted by judges. One of the desirable characteristic of Kulfi related to body and texture is flakiness, which is a consequence of heat denaturation of milk proteins as noted by the sensory panel members. It was observed that Amaranthus contributed to the flakiness of Kulfi prepared by using Amaranthus. The body and texture scores also shown decreasing trend as the level of Amaranthus flour increased in Kulfi. Above 25 parts of the Amaranthus flour added Kulfi possessed a heavy and chewy body due to greater water binding property of Amaranthus flour.

This observation is in agreement with that of Giri (2007) in Kulfi supplemented with dietary fiber. He reported that as the level of dietary fiber in Kulfi increased from 0 to 1 per cent the body and texture score decreased from 8 to 6 on nine point hedonic scale. According to Thomas et al., (2019), body and texture score for the Kulfi prepared from $0 \%$, $2 \%, 4 \%$ and $6 \%$ oat flour were $7.90,8.04$, 7.85 and 7.73 respectively. The maximum score for body and texture was associated with the Kulfi prepared using $2 \%$ oat flour. Siva et al., (2019) reported that the mean scores of body and texture of Kulfi having 0 $\%, 5 \%, 10 \%, 15 \%$ and $20 \%$ flaxseed powder, was found in the range of 7.00 to 8.00 .

\section{Colour and appearance}

Colour and appearance score of Kulfi prepared by using Amaranthus, varied from 7.39 to 8.26. Minimum colour and appearance score was obtained for the Kulfi (T4) containing Amaranthus: SMP in the ratio of 100:00, whereas the maximum score was recorded for the samples (T1) containing Amaranthus: SMP in the ratio of 25:75.As the level of Amaranthus flour in experimental Kulfi increased, the scores for colour and appearance decreased significantly from initial 8.26 to 7.39 , respectively. This may be due to the presence of Amaranthus flour particles, which were visible on the product body since Amaranthus flour is not soluble.

Similar result was observed by Giri (2007) in Kulfi supplemented with dietary fiber. He reported that control Kulfi without dietary fiber scored 7.5 while the Kulfi with 1 per cent dietary fiber scored 6.0 for colour and appearance on nine point hedonic scale. Our 
finding is in consonance with the findings of Thomas et al., (2019), who reported that Kulfi prepared using oat flour added at different level viz. 2, 4 and 6 per cent had similar trend in colour and appearance score (i.e. 7.36 to 8.00). As the level of oat flour increased the colour and appearance score decreased. Giri et al., (2012) reported that the color and appearance score awarded for control Kulfi was 8.0, as against 7.0, 6.9 and 6.7 for the samples subjected to 50,60 and $70 \%$ sugar reduction through $0.05,0.06$ and $0.07 \%$ stevia addition respectively. The lower color and appearance score for treated Kulfi was mainly due to lack of desirable brownish appearance. This could be mainly due to reduction in the sucrose level, which is required for development of desirable brown color in Kulfi through caramelization. T1 (i.e. Amaranthus: SMP @ 25:75) sample of Kulfi had uniform creamy white colour throughout the mass, however the colour of product containing higher level of Amaranthus tended to be of intense creamy white colour. It is worthwhile to point out that there was some granules of Amaranthus in case of Kulfi made using Amaranthus: SMP in the ratio of 100:00. Hence, Kulfi containing Amaranthus: SMP in the ratio of 25:75 scored significantly $(\mathrm{P}<0.05)$ higher colour and appearance score compared to the other treatment.

Table.1 Physico-chemical properties of Kulfi made using varying level of Amaranthus

\begin{tabular}{|c|c|c|c|c|c|c|c|c|}
\hline \multirow[t]{2}{*}{ Constituents* } & \multicolumn{5}{|c|}{$\begin{array}{l}\text { Kulfi made using different level of Amaranthus : } \\
\qquad \operatorname{SMP}(w / w)\end{array}$} & \multirow[t]{2}{*}{ SEm } & \multirow[t]{2}{*}{$\begin{array}{c}\text { CD } \\
(\mathbf{0 . 0 5})\end{array}$} & \multirow[t]{2}{*}{$\begin{array}{l}\text { CV } \\
\%\end{array}$} \\
\hline & $\begin{array}{l}25: 75 \\
(\mathbf{T} 1)\end{array}$ & $\begin{array}{c}\mathbf{5 0 : 5 0} \\
(\mathbf{T} 2)\end{array}$ & $\begin{array}{c}75: 25 \\
(\mathrm{~T} 3)\end{array}$ & $\begin{array}{c}\text { 100:0 } \\
\text { (T4) }\end{array}$ & $\begin{array}{c}\text { Control } \\
\text { (T5) }\end{array}$ & & & \\
\hline TS & $\begin{array}{l}36.28 \pm \\
0.18\end{array}$ & $\begin{array}{l}36.20 \pm \\
0.17\end{array}$ & $\begin{array}{l}36.16 \pm \\
0.17\end{array}$ & $\begin{array}{l}36.09 \pm \\
0.17\end{array}$ & $\begin{array}{l}36.31 \pm \\
0.18\end{array}$ & 0.07 & NS & 0.96 \\
\hline Fat & $\begin{array}{l}10.06^{\mathrm{cd}} \\
\pm 0.02\end{array}$ & $\begin{array}{l}10.13^{\mathrm{bc}} \pm \\
0.03\end{array}$ & $\begin{array}{l}10.17^{\mathrm{ab}} \\
\pm 0.03\end{array}$ & $\begin{array}{l}10.23^{\mathrm{a}} \pm \\
0.026\end{array}$ & $\begin{array}{l}10.03^{\mathrm{d}} \pm \\
0.03\end{array}$ & 0.02 & 0.08 & 0.51 \\
\hline Protein & $\begin{array}{l}03.87^{b} \pm \\
0.01\end{array}$ & $\begin{array}{l}03.79^{\mathrm{c}} \pm \\
0.01\end{array}$ & $\begin{array}{l}03.68^{\mathrm{d}} \pm \\
0.02\end{array}$ & $\begin{array}{l}03.60^{\mathrm{e}} \pm \\
0.01\end{array}$ & $\begin{array}{l}04.02^{\mathrm{a}} \pm \\
0.04\end{array}$ & 0.04 & 0.07 & 1.13 \\
\hline Lactose & $\begin{array}{l}05.38^{\mathrm{ab}} \\
\pm 0.03\end{array}$ & $\begin{array}{l}05.31^{b} \pm \\
0.03\end{array}$ & $\begin{array}{l}05.29^{b} \pm \\
0.03\end{array}$ & $\begin{array}{l}05.13^{\mathrm{c}} \pm \\
0.04\end{array}$ & $\begin{array}{l}05.43^{\mathrm{a}} \pm \\
0.03\end{array}$ & 0.03 & 0.09 & 1.14 \\
\hline $\begin{array}{l}\text { Other } \\
\text { Carbohydrate }\end{array}$ & $\begin{array}{l}16.20^{\mathrm{bc}} \\
\pm 0.05\end{array}$ & $\begin{array}{l}16.22^{\mathrm{abc}} \\
\pm 0.05\end{array}$ & $\begin{array}{l}16.26^{\mathrm{ab}} \\
\pm 0.06\end{array}$ & $\begin{array}{l}16.40^{\mathrm{a}} \pm \\
0.06\end{array}$ & $\begin{array}{l}16.03^{\mathrm{c}} \pm \\
0.09\end{array}$ & 0.04 & 0.19 & 0.79 \\
\hline Ash & $\begin{array}{l}00.78^{\mathrm{ab}} \\
\pm 0.01\end{array}$ & $\begin{array}{l}00.76^{\mathrm{bc}} \pm \\
0.01\end{array}$ & $\begin{array}{l}00.75^{\mathrm{bc}} \\
\pm 0.01\end{array}$ & $\begin{array}{l}00.74^{c} \pm \\
0.01\end{array}$ & $\begin{array}{l}00.80^{\mathrm{a}} \pm \\
0.01\end{array}$ & 0.01 & 0.03 & 2.69 \\
\hline Acidity & $\begin{array}{l}00.16 \pm \\
0.00\end{array}$ & $\begin{array}{l}00.16 \pm \\
0.00\end{array}$ & $\begin{array}{l}00.16 \pm \\
0.00\end{array}$ & $\begin{array}{l}00.16 \pm \\
0.001\end{array}$ & $\begin{array}{l}00.16 \pm \\
0.00\end{array}$ & 0.00 & NS & 1.41 \\
\hline $\mathrm{pH}$ & $\begin{array}{l}06.81 \pm \\
0.01\end{array}$ & $\begin{array}{l}06.79 \pm \\
0.01\end{array}$ & $\begin{array}{l}06.79 \pm \\
0.01\end{array}$ & $\begin{array}{l}06.80 \pm \\
0.01\end{array}$ & $\begin{array}{l}06.79 \pm \\
0.00\end{array}$ & 0.00 & NS & 0.18 \\
\hline Viscosity & $\begin{array}{l}27.44^{\mathrm{d}} \pm \\
0.09\end{array}$ & $\begin{array}{l}28.52^{c} \pm \\
0.10\end{array}$ & $\begin{array}{l}29.26^{\mathrm{b}} \pm \\
0.16\end{array}$ & $\begin{array}{l}30.26^{\mathrm{a}} \pm \\
0.15\end{array}$ & $\begin{array}{l}27.18^{\mathrm{d}} \pm \\
0.10\end{array}$ & 0.27 & 0.37 & 0.87 \\
\hline Melting Rate & $\begin{array}{l}35.46^{\mathrm{b}} \pm \\
0.17\end{array}$ & $\begin{array}{l}33.04^{c} \pm \\
0.08\end{array}$ & $\begin{array}{l}31.40^{\mathrm{d}} \pm \\
0.17\end{array}$ & $\begin{array}{l}30.04^{\mathrm{e}} \pm \\
0.10\end{array}$ & $\begin{array}{l}38.69^{\mathrm{a}} \pm \\
0.18\end{array}$ & 0.71 & 0.44 & 0.86 \\
\hline
\end{tabular}


Table.2 Influence of varying level of Amaranthus on the sensory score of Kulfi

\begin{tabular}{|c|c|c|c|c|c|c|c|c|}
\hline \multirow[t]{2}{*}{$\begin{array}{c}\text { Sensory } \\
\text { attributes }\end{array}$} & \multicolumn{5}{|c|}{$\begin{array}{l}\text { Kulfi made using different level of } \\
\text { Amaranthus : SMP }(w / w)\end{array}$} & \multirow[t]{2}{*}{ SEm } & \multirow[t]{2}{*}{$\begin{array}{c}\text { CD } \\
(\mathbf{0 . 0 5})\end{array}$} & \multirow[t]{2}{*}{$\begin{array}{l}\text { CV } \\
\%\end{array}$} \\
\hline & $\begin{array}{l}\text { (T1) } \\
25: 75\end{array}$ & $\begin{array}{c}\text { (T2) } \\
\mathbf{5 0 : 5 0}\end{array}$ & $\begin{array}{l}\text { (T3) } \\
75: 25\end{array}$ & $\begin{array}{c}\text { (T4) } \\
100: 0\end{array}$ & $\begin{array}{l}\text { (T5) } \\
\text { Control }\end{array}$ & & & \\
\hline Flavour (10) & $\begin{array}{l}8.29^{\mathrm{a}} \pm \\
0.18\end{array}$ & $\begin{array}{l}7.72^{\mathrm{ab}} \pm \\
0.16\end{array}$ & $\begin{array}{r}7.50^{\mathrm{b}} \\
\pm 0.24\end{array}$ & $\begin{array}{l}7.32^{\mathrm{b}} \pm \\
0.26\end{array}$ & $\begin{array}{c}7.94^{\mathrm{ab}} \pm \\
0.22\end{array}$ & 0.12 & 0.64 & 5.51 \\
\hline $\begin{array}{l}\text { Body\& } \\
\text { Texture (10) }\end{array}$ & $\begin{array}{l}8.21^{\mathrm{a}} \pm \\
0.12\end{array}$ & $\begin{array}{l}7.71^{\mathrm{abc}} \\
\pm 0.23\end{array}$ & $\begin{array}{l}7.47^{\mathrm{bc}} \\
\pm 0.24\end{array}$ & $\begin{array}{c}7.36^{\mathrm{c}} \pm \\
0.20\end{array}$ & $\begin{array}{l}8.02^{\mathrm{ab}} \pm \\
0.20\end{array}$ & 0.11 & 0.61 & 5.18 \\
\hline $\begin{array}{l}\text { Colour\& } \\
\text { Appearance (10) }\end{array}$ & $\begin{array}{c}8.26^{\mathrm{a}} \pm \\
0.31\end{array}$ & $\begin{array}{l}7.67^{b} \pm \\
0.16\end{array}$ & $\begin{array}{l}7.47^{\mathrm{b}} \\
\pm 0.09\end{array}$ & $\begin{array}{l}7.39^{\mathrm{b}} \pm \\
0.15\end{array}$ & $\begin{array}{c}7.84^{\mathrm{ab}} \pm \\
0.18\end{array}$ & 0.10 & 0.58 & 4.99 \\
\hline $\begin{array}{l}\text { Overall } \\
\text { Acceptability (10) }\end{array}$ & $\begin{array}{l}8.24^{\mathrm{a}} \pm \\
0.32\end{array}$ & $\begin{array}{l}7.68^{\mathrm{ab}} \pm \\
0.15\end{array}$ & $\begin{array}{r}7.52^{\mathrm{b}} \\
\pm 0.18\end{array}$ & $\begin{array}{l}7.52^{\mathrm{b}} \pm \\
0.14\end{array}$ & $\begin{array}{c}7.94^{\mathrm{ab}} \pm \\
0.11\end{array}$ & 0.10 & 0.59 & 5.03 \\
\hline
\end{tabular}

\section{Overall acceptability}

Since Kulfi made using Amaranthus: SMP in the ratio of 25:75 had significantly $(\mathrm{P}<0.05)$ greater scores for flavour, body $\&$ texture and colour\& appearance, it obviously culminated in such product having significantly superior overall acceptability score compared to the Kulfi made using Amaranthus: SMP in the ratio of 50:50, 75:25, 100:00 and 00:100. This revealed that use of excess level of Amaranthus reduced the overall acceptability of Amaranthus based Kulfi.

Giri et al., (2012) noticed that the overall acceptability score of control Kulfi awarded was 8.2 , as against 7.8, 7.0 and 6.0 for 50, 60 and $70 \%$ sugar reduction through $0.05,0.06$ and $0.07 \%$ stevia addition respectively. Thomas et al., (2019) reported that the level of oat flour increased from 0 to 6 per cent, the overall acceptability scores decreased from 8.08 to 7.40 , respectively. This may be due to the powdery flavour and chewy body contributed by the oat flour. Giri (2007) also reported that fiber addition decreased the overall acceptability of the Kulfi samples due to the chalky flavour and chewy body from 7.5 in control to 6.5 in case of Kulfi with 1 per cent dietary fiber. Siva et al., (2019) stated that the overall acceptability score of flaxseed powder Kulfi with $0 \%, 5 \%, 10 \%, 15 \%$ and $20 \%$ ranged from 7.00 to 8.00. Nalkar et al., (2018) noticed that the incorporation of $15 \%$ mango pulp in Kulfi had the highest score i.e. 8.11 for overall acceptability amongst all the treatments i.e. 0,10 and $20 \%$ mango pulp.

\section{Consumer acceptance trial}

The Kulfi sample manufactured as per the developed formulation was distributed to large number of consumer and their comments were recorded in a specially developed performa. All the consumer liked the product, 31 per cent consumer rated excellent, 57 per cent rated very good and 12 per cent rated good.

\section{Cost of production}

The cost of production of Amaranthus based Kulfi was worked out considering the costs of all the inputs (fixed and variable costs) for a milk handling capacity of $100 \mathrm{~kg} /$ day. It was found that the developed Kulfi could be manufactured at cost of Rs 7.087 per single unit/piece of $60 \mathrm{ml}$, which appeared to be reasonably competitive and quite lower than the control Kulfi i.e. Rs 7.148. 
From the present study, it can be concluded that the use of Amaranthus: SMP in the ratio of 25:75 yielded Kulfi having superior sensory score than that made using Amaranthus: SMP in the ratio of 50:50, 75:25, 100:00 and 00:100 (i.e. control). The cost of production of Amaranthus based Kulfi per single unit/ piece of $60 \mathrm{ml}$ was estimated to be Rs 7.087, which appeared to be reasonably competitive. The energy value that can be gained through consumption of $100 \mathrm{~g}$ of developed Kulfi is $195.891 \mathrm{kcal}$.

\section{References}

AOAC 1995. Official methods of analysis of AOAC International. Association of official analytical chemists. 16th Edn. Virginia, USA.

AOAC 2000. Official methods of analysis of the association of official analytical chemists. 17th Edn. Virginia, USA.

Ashokraju, A., Ali, M.P., Reddy, K.K., Reddy, C.R. and Rama Rao, M. 1989. Studies on the preparation and quality of Kulfi. Indian Journal of Dairy Science. 42(1): 127-29.

Chatterjee, B. and Patel, T. 2016. Increased sensory quality and consumer acceptability by fortification of chocolate flavoured milk with oat $\beta$ glucan. International Journal of Clinical and Biomedical Research. 2(1): 25-28.

Cody, T.L., Olabi, A., Pettingell, A.G., Tong, P.S. and Walker, J.H. 2007. Evaluation of rice flour for use in vanilla ice cream. Journal of Dairy Science. 90: 4575-4585.

Cottrell, J.I.L., Pass, G. and Phillipis, G.O. 1980. The effect of stabilizers on the viscosity of ice cream mix. Journal of the Science of Food and Agriculture. 31: 1066-1070.

Franklin, J.G. and Sharpe, M.E. 1963. The incidence of bacteria in cheese milk and Cheddar cheese and their association with flavour. Journal of Dairy Research. 30(1): 87-99.

FSSR (2011). Food Safety and Standards Act, Rules and Regulations, Professional Book Publishers, New Delhi, India. p. $150 ; 156$.

Ghosh, J. 1991. Process development for the manufacture of instant Kulfi mix powder. Ph.D. Thesis, National Dairy Research Institute (Deemed University), Karnal, India.

Giri, A. 2007. Production of dietetic Kulfi. M.Tech. Thesis, Karnataka Veterinary, Animal and Fisheries Sciences University, Bidar, Karnataka, India.

Giri, A., Rao, H.G. and Ramesh, V. 2012. Effect of partial replacement of sugar with stevia on the quality of Kulfi. Journal of Food Science and Technology. 51(8): 1612-1616.

Guinard, J.X., Liitle, C., Marty, C. and Palchakz, T.R. 1994. Effect of sugar and acid on the acceptability of frozen yogurt to a student population. Journal of Dairy Science. 77: 1232-1238.

Indian Standard SP: 18 part XI 1981. Handbook of Food Analysis- Dairy Products. Bureau of Indian Standards, ManakBhavan, New Delhi, India.

Indian Standard: 1166 1973. Specification for condensed milk. India Standards Institution, ManakBhavan, New Delhi.

Li, Z., Marshall, R., Heymann, H. and Fernando, L. 1997. Effect of milk fat on flavour perception of vanilla Ice cream. Journal of Dairy Science. 80: 3133-3141.

Mohan, B.H., Gopal, A., Malleshi, N.G. and Tharanathan, R.N. 2005. Characteristics of native and enzymatically hydrolyzed ragi (Eleusine coracana) and rice (Oryza sativa) starches. Carbohydrate Polymers. 59: 43-50. 
Muse, M.R. and Hartel, R.W. 2004. Ice cream structural elements that affect melting rate and hardness. Journal of Dairy Science. 87: 1-10.

Naik, A.P. and Londhe, G.K. (2011). Optimization of levels of artificial sweeteners for preparation of sugar freeKulfi. Journal of Dairying, Foods \& Home Science. 30(1): 15-24.

Nalkar, S.D., Patel, A.R., Chandraprakash, V.B. and Kalyankar, S.D. 2018. Studies on suitability of incorporating probiotics in mango-based Kulfi - A popular Indian frozen dessert. Annals Food Science and Technology. 19(4): 714-721.

Nigam, R. 2015. Development of technology for Chhana based Kulfi. M.Tech. Thesis, National Dairy Research Institute, Karnal, Haryana, India.

Patel, A.S., Aparnathi, K.D., Jana, A.H. and Pinto, S. 2009. Utility of sago as a functional ingredient in dietetic chocolate ice cream. International Journal of Food Science Technology and Nutrition. 2(2): 265-276.

Patel, I.J., Dharaiya, C.N. and Pinto, S.V. 2015a. Development of technology for manufacture of ragi ice cream. Journal of Food Science and Technology. 52(7): 4015-4028.

Prindivelle, E.A., Marshall, R.T. and Heymann, H. 1999. Effect of milk fat on the sensory properties of chocolate ice cream. Journal of Dairy Science. 82: $1425-1432$.

Rao, K.S. 1978. Microbiological quality of Kulfi, M.Sc. Thesis, Kurukshetra University, Kurukshetra, Haryana, India.

Ravindran, S. 2003. Development of dietetic Kulfi. M.Sc. Thesis, University of Agricultural Sciences, Bangalore, Karnataka, India.

Rosalina, P., Sofjan, R.P. and Hartel, R.W. 2004. Effects of overrun on structural and physical characteristics of ice cream. International Dairy Journal. 14(3): 255-262.

Salama, F., Azzam, M. and Saad, M. 2017. The use of cereal components in the preparation of Ice Milk. Journal of Environmental Science, Toxicology and Food Technology. 11(5): 38-48.

Salooja, M.K. 1979. Studies on standardization of techniques for Kulfi production. M.Sc. Thesis, Kurukshetra University, Kurukshetra, Haryana, India.

Salooja, M.K. and Balachandran, R. 1982. Studies on the production of Kulfi part-I. The acceptable level of total milk solids. Journal of Food Science and Technology. 19(3): 116-18.

Schmidt, K., Lundy, A., Reynolds, J. and Yee, L.E. 1993. Carbohydrate or protein based fat mimickers effects on ice milk properties. Journal of Food Science. 58: 761-763.

Siddhu, D., Broadway, A.A., Ali, M.N. and Singh, A. 2017. Physico-Chemical and sensory qualities in Kulfi prepared by fruit pomace and bura (Khandsari). The Pharma Innovation Journal. 6(7): 905-907.

Singh, S.B., Das, A. and Kumar, P. 2017b. Effect of incorporation of wood apple pulp on physicochemical, sensory and microbiological properties of Kulfi. Journal of Pharmacognosy and Phytochemistry. 6(6): 574-576.

Siva, K., Das, A., David, J., Bharti, B.K., Kumar, P. and Shukla, S. 2019. Studies on characteristics of flaxseed powder supplemented Kulfi. International Journal of Chemical Studies. 7(3): 924-928.

Thomas, E., Jayaprakasha, H.M. and Venugopal, H. 2019. Effect of supplementation of oat flour on physicochemical and sensory properties of lactose hydrolyzed Kulfi. 
International Journal of Innovative Science and Research Technology. 4(1): 254-258.

USDA 2018. National nutrient database for standard reference full report (All Nutrients) 20001, Amaranth grain, Report Date: July 19, 2019. Available at https://fdc.nal.usda.gov/fdcapp.html\#/?query=ndbNumber:20001, Accessed on 19th July 2019.
Yerriswamy, K., Atmaram, K., Natarajan, A.M. and Anantakrishnan, C.P. 1984. Preparation of sterilized Kulfi mix. Cheiron. 13(5): 223-226.

Yerriswamy, K., Atmaram, K., Natarajan, A.M. and Anatakrishnan, C.P. 1983. Quality of Kulfi manufactured by different methods. Cheiron. 12(3): 130-135.

\section{How to cite this article:}

Patel, A.C., A.J. Pandya, G. Gopikrishna, R.A. Patel, A.M. Shendurse and Roy, S.K. 2020. Development of Kulfi Incorporated with Amaranthus (Rajgara). Int.J.Curr.Microbiol.App.Sci. 9(05): 612-625. doi: https://doi.org/10.20546/ijcmas.2020.905.068 